e-ISSN: 2550-1313 | p-ISSN: 2087-9849

http://jurnal.fkip.unila.ac.id/index.php/jpp/

\title{
The Correlations among English Teachers' TPACK, TISE, ITOE, and Teaching Implementation
}

\author{
Aresti Randika, Sofendi, Machdalena Vianty \\ Department of English Education, Sriwijaya University, Indonesia \\ *Corresponding email: sofendi@yahoo.com
}

Received: 04 December $2020 \quad$ Accepted: 11 December $2020 \quad$ Published: 20 December 2020

Abstract: The Correlations among English Teachers' TPACK, TISE, ITOE, and Teaching Implementation. Objectives: This research is correlational research that aimed to find out the correlations among Technological Pedagogical Content Knowledge (TPACK), Technology Integration Self-Efficacy (TISE), Instructional Technology Outcome Expectation (ITOE), and Teaching Implementation. Methods: TPACK-EFL Survey and Motivation of Technology Integration in Education Scale Questionnaires were distributed to 60 students of the English language teacher professional education program at Sriwijaya University in the academic year 2018/2019. Findings: The findings of this research showed that the students have a high understanding level of TPACK, high level of TISE, high level of ITOE, and good in teaching implementation, and there are positive significant correlations among TPACK, TISE, ITOE, and teaching implementation. Conclusion: Not only the technical equipment but also the qualified teachers who understand how to advance the ICT are very needed. Therefore, both understanding TPACK and acquiring TISE-ITOE are necessary.

Keywords: Teacher Professional Education Program (PPG), TPACK, TISE, ITOE.

Abstrak: Hubungan antara TPACK, TISE, ITOE, dan Pelaksanaan Pembelajaran oleh Guru Bahasa Inggris. Tujuan: Penelitian ini merupakan penelitian korelasional yang bertujuan untuk mengetahui hubungan antara Technological Pedagogical Content Knowledge (TPACK), Technology Integration Self-Efficacy (TISE), Instructional Technology Outcome Expectation (ITOE), dan Pelaksanaan Pembelajaran. Metode: Survei TPACK-EFL dan Motivasi Integrasi Teknologi dalam Skala Pendidikan Kuesioner dibagikan kepada 60 siswa program pendidikan profesi guru bahasa Inggris di Universitas Sriwijaya pada tahun ajaran 2018/2019. Temuan: Hasil penelitian menunjukkan bahwa siswa memiliki tingkat pemahaman TPACK yang tinggi, tingkat TISE yang tinggi, tingkat ITOE yang tinggi, dan pelaksanaan pembelajaran yang baik, serta terdapat korelasi positif yang signifikan antara TPACK, TISE, ITOE, dan pelaksanaan pembelajaran. Kesimpulan: Tidak hanya peralatan teknis tetapi juga guru-guru berkualitas yang memahami bagaimana memanfaatkan Teknologi Informasi dan Komunikasi sangat dibutuhkan. Oleh karena itu, pemahaman TPACK dan akuisisi TISE-ITOE diperlukan.

Kata kunci: Program Profesi Guru (PPG), TPACK, TISE, ITOE.

To cite this article:

Randika, A., Sofendi., \& Vianty, M. (2020). The Correlations among English Teachers' TPACK, TISE, ITOE, and Teaching Implementation. Jurnal Pendidikan Progresif, 10(3), 513-525. doi: 10.23960/jpp.v10.i3.202013. 


\section{INTRODUCTION}

Education means a lot in everyone's life as it facilitates learning, knowledge, and skill. Compared to other countries, Indonesia is left behind. EF EPI(English Proficiency Index) ranks Indonesia in $39^{\text {th }}$ place out of 80 countries in 2017. The score of EF EPI of Indonesia is 52,15 which is categorized as low proficiency. In Asia, similarly, Indonesia is categorized as having a low English proficiency - it is ranked in the $10^{\text {th }}$ place out of 20 countries surveyed by EF EPI. There is also a comparison among the provinces in Indonesia which shows that South Sumatera is in the $9^{\text {th }}$ place out of 12 provinces surveyed by EF EPI which also indicates a low proficiency.

The teaching and learning process at school is a way to obtain an education. The students who attend the class expect the teachers to be their bridge to gain and develop more knowledge and skill. In this $21^{\text {st }}$ century, not only mastering the material, but students are also required to have a proportional understanding of technology. It is stated in Partnership for $21^{\text {st }}$ Century Learning (2017) that Information and Communication Technology (ICT) literacy is considered as one skill that students are expected to master. It can help students in their learning. For example, according to Young (2003), ICT can increase interaction among students and real-life situations that can derive the students to understand the material more. Google Earth, developed by Keyhole, Inc. in 2004, is one example of an advanced technology that may be used to teach geography, astronomy, and so on. Teachers can show the students the real description of how the earth looks from space and also the description of outer space. ICT also can support the English language teaching and learning process. The teachers can use various relevant videos from YouTube, or have an online group consisted of the students and also a native speaker of the English language so that the students can obtain the experience to have a chit chat with the native. The writer also found that one of the lecturers in a big university has implemented the use of Facebook as the tool either to do the students' assignments or to assess the students' writing through the Peer Comment on Facebook (Inderawati, 2011). In brief, integrating computers in teaching and learning languages has become more useful and effective with the support of multimedia and the internet (Kose, 2016). It is added that the teachers' perspective through TPACK and the relationships among technology, content, and pedagogy can affect the teachers' ability to use technology in the teaching and learning process.

Technology can be a powerful means of transforming learning. According to Smith and Shotsberger (2011), most pre-service teachers stated that technology had a necessary role in education. It can help affirm and improve relationships between teachers and students, reinvent the approaches to learning and collaboration, shrink long-standing equity and accessibility gaps, and adapt learning experiences to meet the needs of all students (Reimagining the Role of Technology in Education, 2017). Then, twenty-first-century skills that include learning, collaborating, problem-solving, and creative and innovative thinking also require the students to be able to use Information and Communication Technologies (ICT) as a means to enlarge their knowledge. Moreover, the teachers are also required to make the students aware of the importance of applying the knowledge that they are studying in the class to real-life as the community expects the students to be familiar and get used to technology-based education activity. To make the students literate in ICT, there must be teachers who are more literate since teachers are responsible to teach and to be good role models for the students. Ingersoll and Collins (2018) once stated that teachers are often 
considered the backbone of a school where the students are having a learning process. Besides, the use the technology is also an important competence that the teachers should have (Ruggiero \&Mong, 2015). Thus, the presence of a qualified and professional teacher is really important to improve the students' development because to help students to be well prepared to use ICT in their learning, they need some qualified teachers to help them in both understanding the material and the technology or ICT.

Research conducted by Koehler, Mishra, Kereluik, Shin, and Graham (2013) has shown that teachers are not adequately equipped with the knowledge required for successful technology integration. In addition, a moderate level of TPACK was found in Mathematics teachers of primary schools in Kudus that indicated the teachers had known the concept of TPACK well, but they couldn't apply their knowledge to the teaching process (Wahyuni \& Pratiwi, 2019). To have qualified teachers, one of the Indonesian government's efforts is by certifying teachers which is implemented through the Teacher Professional Education Program or PendidikanProfesi Guru (PPG). This program takes six months for a classroom session and another six months for having teaching experience in schools. Based on Undang-Undang No. 12 the Year 2012, PPG is an education program that prepares undergraduate education students and non-undergraduate education students who have the interest to be a teacher so that they can get the professional teacher certificates. The aims of conducting PPG are to produce teacher candidates who have the competencies to plan, implement, and assess learning, to follow up the results of the assessment by mentoring, and student training, and to be able to conduct research and develop professionalism sustainability. Thus, this program is expected to produce professional qualified future teachers who can teach and lead their students to be competitive, superior, having good characteristics, and love the country. In addition, as it is stated clearly in Permendiknas No. 16 the Year 2007 about teachers' competence and academic qualification standard that teachers of each subject are required to use the ICT for teaching and learning process, it means that the teachers are the very first stakeholder that must be ready to be able to integrate the technology in teaching and learning process.

\section{Technological Pedagogical Content Knowledge}

According to Koehler and Mishra (2008, 2009) Technological Pedagogical and Content Knowledge or TPACK is an understanding that emerges from an interaction of content, pedagogy, and technology knowledge that is aimed at supporting teachers' skill development for acquiring and explaining how technologyrelated subject-specific knowledge is applied during teaching and learning activities. The conception of Technological Pedagogical and Content Knowledge (TPACK) described here has developed over time through a series of publications, with the most complete descriptions of the framework founding Mishra and Koehler (2006) and Koehler and Mishra (2008). The Technological Pedagogical and Content Knowledge (TPACK) framework builds on Shulman's $(1987,1986)$ descriptions of Pedagogical Content Knowledge to describe how teachers' understanding of educational technologies and Pedagogical Content Knowledge interact with one another to produce effective teaching with technology. Therefore, TPACK is simply defined as an understanding of the teachers to deliver the material with the use of technology appropriately. 


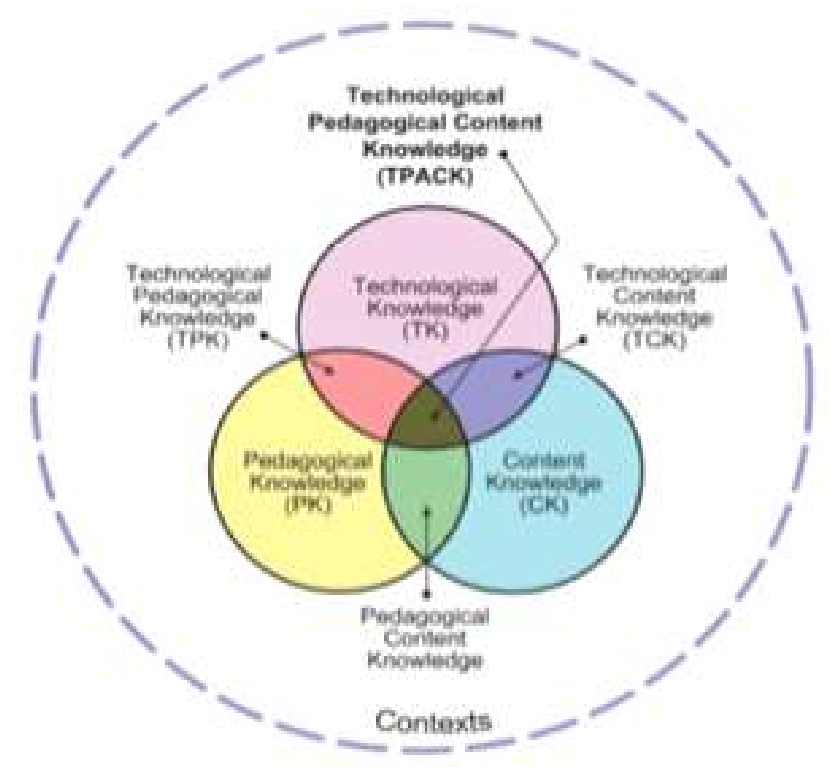

Figure 1: The TPACK framework (reproduced by permission of the publisher, (C2012 by http:// tpack.org)

Technology Integration Self-Efficacy and Instructional Technology Outcome Expectations

Bandura's Social Cognitive Theory (1986) and its two main constructs, self-efficacy and outcome expectations, have received a great deal of attention in the field of educational technology (Wang, Ertmer\& Newby, 2004; Perkmen\&Pamuk, 2011). Self-efficacy can be defined as people's beliefs about their ability to accomplish a given task whereas outcome expectations refer to their anticipated outcomes of an action (Bandura, 1997) or an intrapersonal factor that influences their motivation. Similarly, according to Niederhauser and Perkmen (2010), instructional technology outcome expectations (ITOE) is the motivational force influencing a teacher to use technology during instruction, along with the anticipated outcomes of using instructional technology in the classroom (Perkmen, 2008). Technology integration in teaching and learning is one of the critical elements to be taken care of especially by the teacher.
Teachers who have a high technology integration self-efficacy are likely to believe that they have the necessary skills to use instructional technology in the classroom. While those who possess positive outcome expectations probably expect that technology will make a positive and remarkable contribution to their teaching practices.

\section{Previous Related Studies}

There have been many studies focusing on the investigation ofTPACK. Semiz and Ince (2012) found a good level and positive relationships among TPACK, TISE, and ITOE of pre-service physical education teachers in Turkey. Perkmen and Surmelioglu (2016) found a moderate relationship between technology integration self-efficacy and outcome expectations. Although these two constructs seemed to differ, they are conceptually related. Other research studies also found a moderate relationship between these two constructs (Niederhauser\&Perkmen, 2008，2010; 
Perkmen, 2014; Sahin, 2008) which suggested that those who believe to have high educational technology self-efficacy tend to expect positive outcomes or contributions from using educational technology in the classroom. Similaryly, Ariani (2015), Wahyuni and Pratiwi (2019) also found out a significant correlation between TPACK and TISEofMathematics primary teachers in Banjarmasin and Kudus, Indonesia. TPACK and TISE capability of the teachers is important to develop their integrated technology competence in teaching, while Technology integration selfefficacy and outcome expectations are also important because they affect technology integration performance (Perkmen\&Pamuk, 2011). These were compatible with the result of previous research conducted by Oskay (2017) stated that educational technology standards had an important effect on the teachers' pedagogical content knowledge. The educational technology standards were consisted of six categories and required in the primary concept of teaching implementation. It means that for effective and successful language learning and teaching, it is important to reveal the perceptions of the teachers' self-efficacy and outcome expectation on technology integration into language teaching and how they use technology with content and pedagogy.

Based on the above-mentioned studies, they showed that there were positive correlations among TPACK, TISE, ITOE, and teaching implementation. However, the writer didn't find any study that investigated the whole variables as one. Therefore, this research aimed to identify the correlations amongTPACK, TISE, ITOE, and teaching implementation of the students of English language teacher professional education; and examine the relationships between TPACK and teaching implementation, TISE and teaching implementation, also ITOE and teaching implementation.

\section{METHODS}

The writer conducted correlational research in this study as the purpose of its research is to find out the relationship or correlation among the variables. Correlational research is research that allows the researcher to predict the outcomes. In another hand, it can be used to predict the outcomes of one variable according to the known results of another variable that is related to the research.

There are two techniques were used to collect the data, firstly by asking for students' opinion by distributing ready-made questionnaires namely TPACK-EFL Survey and Motivation of Technology Integration in Education Scale, and by collecting the students' scores of their final examination namely UjiKinerja (UKIN)documented by the English language teacher professional education of SriwijayaUniverasity. Because the questionnaires couldn't be distributed directly to the students due to the long-distance and pandemic situation (COVID-19), the writer distributed the questionnaires in form of Google Form that is spread through social media.

\section{Population and Sample}

According to Creswell (2012, p. 142), "Population is a group of individuals who have the same characteristic". While the sample is a subgroup of the target population that the researcher plans to study for generalizing about the target population (Creswell, 2012). The population in this research is in-service students of English language teacher professional education of Sriwijaya University (UNSRI) in the academic year 2018/2019. The sample consisted of 14 male students and 46 female students so the total number of students who voluntarily filled the questionnaires was 60 . Because it was less than 100 , so the writer took all the population to be the sample. 


\section{INSTRUMENTS Questionnaires of TPACK}

The first questionnaire, taken from Baser (2015), is consisted of 39 items. According to Sugiyono (2010), a questionnaire is a technique for collecting data by providing questions to be answered by the respondent. Therefore, the questionnaire contained some questions that referred to the students' understanding of TPACK and each domain. It consists of seven parts: Technological Knowledge (TK), Content Knowledge (CK), Pedagogical Knowledge (PK), Pedagogical Content Knowledge (PCK), Technological Content Knowledge (TCK), and Technological Pedagogical Knowledge (TPK), and also Technological Pedagogical and Content Knowledge (TPACK). The TPACK Survey consists of 1 until 9 interval score that is analyzed into five categories from very low until very high.

Questionnaires of Technology Integration Self-Efficacy and Instructional Technology Outcome Expectation

The motivation of the Technology Integration in Education Scale was used in this study to measure teachers' self-efficacy. This instrument consisted of 6 items. In addition, there are 9 items regarding technology integration in education to find out the instructional technology outcome expectation of the teachers. This scale has been designed based on other technology integration scales (Niederhauser\&Perkmen, 2008 ; 2010) and social cognitive theory. Some of the items regarding self-efficacy included "I feel confident that I have the necessary skills to use instructional technology in the classroom" and "I feel confident that I can help students when they have difficulty using instructional technology in the classroom". Outcome expectations consisted of three dimensions: performance, selfevaluative, and social. Each dimension consisted of three items. The stems for all of the outcome expectations were "Using instructional technology in my classroom will likely allow me to....”. Some of the items were "... will increase my productivity" and "... will make teaching more exciting". Besides, a Likert Scale is used in both questionnaires to inquire about the frequency of adaptation challenges in five-level from 1 until 5.

\section{Teaching Implementation}

For the teaching implementation, the writer sent the written permission to the head of English language teacher professional education program at Sriwijaya University. The teaching implementation data were taken from teacher evaluation instrument scores that were evaluated by the instructors of English language teacher professional education program at Sriwijaya University while the students were having teaching and learning internship at schools. The names of the sample were not mentioned in the research as the scores of the final examination of teaching at schools were not an accessible document for the public.

\section{Validity and Reliability of Questionnaires}

There are two types of items in the questionnaire namely open and closed form. The questionnaires used in this research are closed forms. Closed forms are best for obtaining demographic information and data can be categorized easily (McMillan and Schumacher, 2010). The questionnaires are considered reliable since the two questionnaires are ready-made. It can be concluded that the questionnaires are appropriate and valid to be used.

\section{Technique for Analyzing the Data}

After all the data were collected, the writer used the Pearson correlation product-moment coefficient to answer the research questions. The Pearson Product Moment Correlation Coefficient formula was used to find out whether 
or not there are significant correlations among Technological Pedagogical Content Knowledge (TPACK), Technology Integrated Self Efficacy (TISE), Instructional Technology Outcome Expectations (ITOE), and teaching implementation of English teachers joining teacher professional education program at Sriwijaya University (UNSRI). Then, regression analysis was applied to find out the contribution of Teachers' Technological Pedagogical Content Knowledge (TPACK), Technology Integration SelfEfficacy (TISE), and Instructional Technology Outcome Expectation (ITOE) as the predictor variables to the Teaching Implementation as the criterion variable.

\section{RESULTS AND DISCUSSION}

The findings consisted of the correlation results 1) between the students' understanding of Technological Pedagogical and Content Knowledge (TPACK) and teaching implementation, the students' Technology Integration Self-Efficacy (TISE) and teaching implementation, the students' Instructional Technology Outcome Expectation(ITOE) to the teaching implementation 2) among the students' understanding of TPACK, TISE, ITOE and teaching implementation. The data wereobtained by distributing the questionnaires to the in-service students of English language teacher professional education of Sriwijaya University (UNSRI) in the academic year 2018/2019.

\section{Normality and Homogeneity of the Tests}

The writer used Kolmogorov-Sminov to find out the normality of the data. The result showed that the $p$-value of Scores of UKIN was 0.200 , Questionnaire of TPACK was 0.200 , and Questionnaire of TISE was 0.072. The p-values were higher than 0.05 , therefore the data were normallydistributed.
The result of homogeneity test showed that the sig value from the test was 0.00 . The sig value was lower than 0.05 which indicated that the population did not have the samevariant. Therefore, to analyze the correlations among the variables, the writer used a non-parametric correlation test, namely Spearman's Rank Correlation Coefficient.

\section{Technological Pedagogical and Content Knowledge (TPACK)}

The students of English language teacher professional education at Sriwijaya University had 6.10 for a minimum score and 8.77 for the maximum score. Since the mean score of the TPACK questionnaire was 7.46 , the writer concluded that the students' understanding of TPACK was high.

Based on table 1, the result of the students' TPACK questionnaire showed that none of the students of English language teacher professional education at Sriwijaya University was in the low and very low category. The findings showed that most of the students (78\%) were in high understanding of TPACK and only 6 students $(10 \%)$ were in very high understanding of TPACK.

Table 1. The Result of TPACK Questionnaire

\begin{tabular}{c|c|c|c}
\hline $\begin{array}{c}\text { Scores } \\
\text { Interval }\end{array}$ & Category & $\begin{array}{c}\text { No. of } \\
\text { Student(s) }\end{array}$ & Percentage \\
\hline 9 & Very High & 6 & $10 \%$ \\
\hline $7-8$ & High & 47 & $78 \%$ \\
\hline $5-6$ & Moderate & 7 & $12 \%$ \\
\hline $3-4$ & Low & 0 & $0 \%$ \\
\hline $1-2$ & Very Low & 0 & $0 \%$ \\
\hline
\end{tabular}

Therefore, it could be concluded that the students of English language teacher professional education at Sriwijaya University have a high understanding of Technological Pedagogical 
Content Knowledge. It means that the students are aware of TPACK concept well and can apply their awareness to the teaching implementation. The results are compatible with the result of research conducted by Oskay (2017), it was stated that the teachers in Turkey had a high level of TPACK. In line with this, Septiyanti, Inderawati, and Vianty (2020) also stated that the English education undergraduate students of Teacher Training and Education at the University of Lampung had a good TPACK perception.

\section{Technology Integration Self-Efficacy (TISE)}

The result of the students' TISE questionnaire in Table 2 showed that none of the students of English language teacher professional education at Sriwijaya University was in low and very low level. The findings showed that almost half of the students (48\%) were at a high level of TISE and $45 \%$ of others were at a very high level of TISE. There were only 4 students (7\%)at a moderate level of TISE.

Table 2. The Result of TISE Questionnaire

\begin{tabular}{c|c|c|c}
\hline $\begin{array}{c}\text { Scores } \\
\text { Interval }\end{array}$ & Category & $\begin{array}{c}\text { No. of } \\
\text { Student(s) }\end{array}$ & Percentage \\
\hline 5 & Very High & 27 & $45 \%$ \\
\hline 4 & High & 29 & $48 \%$ \\
\hline 3 & Moderate & 4 & $7 \%$ \\
\hline 2 & Low & 0 & $0 \%$ \\
\hline 1 & Very Low & 0 & $0 \%$ \\
\hline
\end{tabular}

The students of English language teacher professional education at Sriwijaya University had 3.44 for a minimum score and 5.00 for the maximum score, while the mean score was 4.38. Since the mean score of the TISE Questionnaire was 4.38 , the writer concluded that the students' level of TISE is high. The results is in line with Brisci and Kul (2018) who found that the preservice teachers in Turkey had high levels of technology integration self-efficacy beliefs.

\section{Instructional Technology Outcome Expectation (ITOE)}

The students of English language teacher professional education at Sriwijaya University had 3.56 for a minimum score and 4.89 for the maximum score. Since the mean score of the ITOE Questionnaire was 4.40 , the writer concluded that the students' level of ITOE is high.

Table 3. The Result of ITOE Questionnaire

\begin{tabular}{c|c|c|c}
\hline $\begin{array}{c}\text { Scores } \\
\text { Interval }\end{array}$ & Category & $\begin{array}{c}\text { No. of } \\
\text { Student(s) }\end{array}$ & Percentage \\
\hline 5 & Very High & 32 & $53 \%$ \\
\hline 4 & High & 28 & $47 \%$ \\
\hline 3 & Moderate & 0 & $0 \%$ \\
\hline 2 & Low & 0 & $0 \%$ \\
\hline 1 & Very Low & 0 & $0 \%$ \\
\hline
\end{tabular}

Based on table 3, the result of students' ITOE questionnaire showed that $53 \%$ or more than a half of students of English language teacher professional education at Sriwijaya University was in a veryhigh level of ITOE, while 28 students (47\%) were in a high level of ITOE. The findings showed that none of the students was in moderate, low, and very low level of ITOE. The high levels of TISE and ITOE indicated the students were optimist and very confident that their ability to integrate the technology can help the teaching and learning process in the classroom. The students can choose the appropriate way to use technology in the classroom and make the materials easier to be received.

\section{Teaching Implementation}

The students of English language teacher professional education at Sriwijaya University had 75.27 for a minimum score and 89.12 for the maximum score. Since the mean score of teaching implementation was 82.56 , the writer concluded that the students' level of teaching implementation was good. 
Table 4. The Result of Teaching Implementation

\begin{tabular}{c|c|c|c}
\hline $\begin{array}{c}\text { Scores } \\
\text { Interval }\end{array}$ & Category & $\begin{array}{c}\text { No. of } \\
\text { Student(s) }\end{array}$ & Percentage \\
\hline $90-100$ & Very good & 0 & $0 \%$ \\
\hline $80-89$ & Good & 48 & $80 \%$ \\
\hline $70-79$ & Moderate & 12 & $20 \%$ \\
\hline$<70$ & Low & 0 & $0 \%$ \\
\hline
\end{tabular}

Based on table 4, the result of students teaching implementation showed that most of the students of English language teacher professional education at Sriwijaya University were in good teaching implementation, while 12 students $(20 \%)$ were in a moderate level of teaching implementation. The findings showed that none of the students was in a very good and low level of teaching implementation. Since the students of English language teacher professional education program are in-service teachers who have taught in some schools, the writer assumed that they were helped by their experiences both from micro-teaching practices in teacher professional education programs and from conducting the English classes at schools.

\section{The Correlation Analysis}

Firstly, there is a positive significant correlation between TPACK $\left(\mathrm{x}_{1}\right)$ and teaching implementation (y) of the students of English language teacher professional education at Sriwijaya University. In addition, the correlation coefficient is 0.705 which indicated a strong correlation between the variables. Second, there is a positive significant correlation between TISE $\left(\mathrm{x}_{2}\right)$ and teaching implementation $(\mathrm{y})$ of the students of English language teacher professional education at Sriwijaya University. In addition, the correlation coefficient is 0.609 which indicated a strong correlation between the variables. Third, there is a positive significant correlation between $\operatorname{ITOE}\left(\mathrm{x}_{3}\right)$ and teaching implementation (y) of the students of English language teacher professional education at Sriwijaya University. In addition, the correlation coefficient is 0.698 which indicated a strong correlation between the variables. The last correlation analysis also showed a positive significant correlation between the predictor variables (TPACK, TISE, and ITOE) and the criterion variable (Teaching Implementation). It indicated that the higher level of TPACK, TISE, and ITOE the students have, the higher the teaching implementation theywill get.

The students of teacher professional education programs are in-service teachers who have taught in some schools. Thus, their experiences in real classroom environments helped them to integrate technology confidently and decide how to create a positive atmosphere that can engage the students to enjoy the teaching and learning process as well as to understand the materials. In addition, they also joined the teacher professional education program which required them to plan, implement, and assess learning integrated with technology. They become accustomed either to design the lesson plan which is integrated with technology or to build the classroom activity with the use of ICT as they usually conducted similar teaching practices during the program. This also implies that the students believed they had sufficient knowledge and could integrate the use of technology in the English language subject both on content and pedagogical matters. In addition, the predictor variables explain $59.3 \%$ of the variability in students' teaching implementation, while the contributions given from each predictor variable to criterion variable vary from $46 \%$ (TPACK), $10 \%$ (TISE), to $0.33 \%$ (ITOE). It means that TPACK contributed $46 \%$ to teaching implementation and became the highest contributor among others. This result is compatible with the research result conducted by Cheng and Xie (2018) which stated that the value belief was not the significant predictor for TPACK since the teachers' confidence and motivation were controlled. 


\section{CONCLUSIONS}

Teaching implementation is one of the successful keys to success the teaching and learning in the classroom. The teachers play an important role in delivering the material to the students so they can receive knowledge as much as possible both from the teachers and the materials. Besides, the teachers must be aware of the TPACK, TISE, and ITOE impacts on student learning. In this twenty-first-century, especially in some areas in Indonesia that now are applying distance education due to Covid19 , not only the technical equipment but also the qualified teachers who understand how to advance and use ICT are very needed. Therefore, understanding TPACK, TISE, and ITOE are necessary. In addition, the findings imply that not only from the school where they teach but the students also get many benefits from joining the teacher professional education program. During the teaching and learning process, the students got experiences and supervision either to design the lesson plan integrated with the technology, to use and enrich their knowledge and skills of using ICT, or to get the classroom management practices by teaching and integrating the technology in the real classroom in some schools.

Based on the conclusions above, there are some suggestions to be offered to the students, teachers, and future researchers. First, the results of the correlation indicated that the higher level of TPACK, TISE, and ITOE the students have, the better the teaching implementation they will apply in classes. Therefore, to improve the teaching implementation quality, the writer suggests the educators, from the future teacher and the professional teachers to keep updating their knowledge and skill about TPACK, gaining a higher level of TISE and ITOE. Getting involved in any educational seminar, training, or registering to the English language teacher professional education program can be the best choice to upgrade the teachers' qualifications too. Then, the limitation of this research is the number of samples. For further research who wants to conduct the same or similar research, the writer suggests adding larger samples so that the results can be used to generalize a wider area, to draw a larger conclusion, and to give more advantages.

\section{REFERENCES}

Act of the Republic of Indonesia number 16, year 2007 on teachers' competence. (n.d.). Retrieved November 11, 2019 from http:/www.flevin.com/id/lgso/ translations/Laws/Law\%20No.\%2 020\%20of\%20203\%20on\%20the \%20 National\%20Education \%20System $\% 20 \% 28$ BKPM\%29.pdf

Act of the Republic of Indonesia number 12, year 2012 on higher education system. (n.d.). Retrieved November 11, 2019 from http://kelembagaan.ristekdikti.go.id/ /wp-content/upload/206/08/ 12777242644.pdf

Ariani, D.N. (2015). Hubungan antara technological pedagogical content knowledge dengan technology integration self-efficacy guru matematika di sekolah dasar. Muallimuna Jurnal Madrasah Ibtidaiyah. 1(1).80-89.

Bandura, A. (1986). Social foundations of thought and action: A social cognitive theory. New Jersey, NJ: Prentice Hall.

Bandura, A. (1997). Self-efficacy: The exercise of control. New York, NY: Freeman.

Baser, D. (2015). Development and evaluation of a technological pedagogical content knowledge (TPACK) assessment tool for pre-service teachers learning to teach English as a foreign language. Graduate thesis, Computer Education and Instructional Technology Department, Middle East Technical University, Turkey. 
Birisci, S., \& Kul, U. (2019). Predictors of technology integration self-efficacy beliefs of preservice teachers. Contemporary Educational Technology, 10(1), 75-93. https://doi.org/10.30935/cet.512537

Celik.I., Sahin, I., \&Akturk, A.O. (2014). Analysis of the relations among the components of technological pedagogical and content knowledge (TPACK): a structural equation model. J. Educational Computing Research.51(1), 1-22

Cheng, S., \&Xie, K. (2018). The relations among teacher value beliefs, personal characteristics, and TPACK in intervention and non-intervention settings. Teaching and Teacher Education, 74, 98-113. https://doi.org/10.1016/j.tate.2018.04. 014 .

Creswell, J. W. (2012). Educational research: Planning, conducting, and evaluating quantitative and qualitative research $\left(4^{\text {th }}\right.$ ed.). Boston, MA: Pearson Education, Inc.

EF EPI. (2017). EF English proficiency index 2017: The world's largest ranking of English skills. Retrieved October 6, 2019 from http://www.ef.co.id/epi/

Huang, Z. (2017). Theoretical analysis of TPACK knowledge structure of mathematics teachers based on T-TPACK mode. Educational Sciences: Theory \& Practice. 18(5), 2044-2053.

Inderawati, R. (2011). From Classroom to Peer Comment in Facebook: Bridging to Establish Learners'Literacy. International Conference "ICT for Language Learning” 4th edition. Indonesia: Pixel.

Ingersoll, R.M. \& Collins, G.J. (2018). The Status of Teaching as a Profession.In J. Ballantine, J. Spade, and J. Stuber (Eds.), Schools and Society: A Sociological Approach to Education (p. 199-213) 6th Ed.
California, CA: Pine Forge Press/Sage Publications.

Koehler, M. \& Mishra, P. (2008).Introducing TPCK. In: AACTE Committee on Innovation Technology (Eds.). Handbook of Technological Pedagogical Content Knowledge (TPCK) for Educators (p. 3-29). London: Routledge Taylor and Francis Group.

Koehler, M.J., \& Mishra, P. (2009). What is technological pedagogical content knowledge. Contemporary Issues in Technology and Teacher Education, 9(1), 60-70.

Koehler, M.J., Mishra, P., Kereluik, K., Shin, T.S., \& Graham, C. (2013). The Technological Content Knowledge Framework. In M.J. Spector, M.D. Merrill, J. Elen\& M. J. Bishop(Eds.) Handbook of research on educational communications and technology. 101111). New York, NY: Springer.

Kose, N.K. (2016). Technological pedagogical content knowledge (TPACK) of English language instructors. Journal of educational and instructional studies in the world. 6(2), 12-19.

McMillan, J. H., \& Schumacher, S. (2010). Research in education: Evidence based inquiry ( $7^{\text {th }}$ ed.). Englewood Cliffs, $\mathrm{NJ}$ : Pearson Education.

Mishra, P. \& Koehler, M. J. (2006). Technological pedagogical content knowledge: A framework for integrating technology in teacher knowledge. Teachers CollegeRecord, 108(6), 10171054.

Niederhauser, D. S., \&Perkmen, S. (2008). Validation of the Intrapersonal Technology Integration Scale: Assessing the influence of intrapersonal factors that influence technology integration. Computers in the 
Schools, 25(12), 98-111

Niederhauser, D. S., \&Perkmen, S. (2010). Beyond self-efficacy: Measuring preservice teachers' instructional technology outcome expectations. Computers in Human Behavior, 26(3), 436-442.

Oskay, O. O. (2017). An investigation of teachers' self efficacy beliefs concerning educational technology standards and technological pedagogical content knowledge.Eurasia Journal of Mathematics, Science and Technology Education, 13(8), 4739-4752.https:// doi.org/10.12973/eurasia.2017.00961a

Partnership for $21^{\text {st }}$ Century Learning. (2008). 21st Century Skills: How can you prepare students for the new Global Economy?.Charles Fadel Global Lead, Education Cisco Systems, Inc.

Perkmen, S. (2008).Factors that influence preservice teachers' technology integration performance. Doctoral Dissertation, Iowa State University, 2008. Dissertation, Abstracts International, 69(06), 109.

Perkmen, S., \&Pamuk, S., (2011).Social cognitive predictors of pre-service teachers' technology integration performance.Asia Pacific Education Review, 12(1), 45-58.

Perkmen, S. (2014). The role of personality and school climate on pre-service teachers' motivation towards technology integration in education.NWSA-Education Science, 9(4), 380-393.

Puspitarini, E.W., Sunaryo, S., \&Suryani, E. (2013). Pemodelan technological pedagogical content knowledge (TPACK) berbasis teknologi informasi dan komunikasi (TIK) dengan pendekatan structural equation modeling (SEM). Prosiding Seminar Nasional Manajemen Teknologi XVIII
Ruggiero, D., \&Mong, C. J. (2015). The teacher technology integration experience: Practice and reflection in the classroom. Journal of Information Technology Education: Research, 14, 161-178

Sahin, Ý. (2008). From the social-cognitive career theory perspective: A college of education faculty model for

explaining their intention to use educational technology. Journal of Educational Computing Research, 38(1), 51-66.

Semiz, K., \&Ince, M.L. (2012).Pre-service physical education teachers' technological pedagogical content knowledge, technology integration self-efficacy and instruction technology outcome expectations.Australasian Journal of Educational Technology, 28(7). https:// doi.org/10.4742/ajet.800

Septiyanti, M., Inderawati, R., \&Vianty, M. (2020). (TPACK) Perception of English Education Students.English Review: Journal of English Education, 8(2), 165174. https://doi.org/10.25134/ erjee.v8i2.2114.Received

Shulman, L. S. (1986). Those to understand: Knowledge growth in teaching. Educational Researcher, 15(2), 4-14.

Shulman, L. S. (1987). Knowledge and teaching: Foundations of the new reform. Harvard Educational Review, 57(1), 1-22.

Smith, K. B. \& Shotsberger, P. G. (2001). Webbased teacher education: Improving communication and professional knowledge in preservice and in-service teacher training. Retrieved on 11 April 2018 from http://www.eric.ed.gov/ ERICDocs/data/ericdocs 2 sql/ content_storage_01/0000019b/80/19/7c/ a1.pdf on 07.12.2017.

Sugiyono, 2010.Metode Penelitian Kuantitatif Kualitatif dan R\&D. Bandung: Alfabeta. 
U.S. Department of Education. (2017). Reimagining the Role of Technology in Education: 2017 National Education Technology Plan Update. Retrieved November 14, 2019 from http:// tech.ed.gov

Young, S. S. C. (2003). Integrating ICT into second language education in a

vocational high school.Journal of Computer Assisted Learning, 19(4), 447-461.

Wahyuni, F. T., \& Pratiwi, A. D. (2019). Hubungan antara Technological Pedagogical Content Knowledge (TPACK) dengan Technology Integration SelfEfficacy (TISE) Guru Matematika di Madrasah Ibtidaiyah. Jurnal Pendidikan Matematika, 2(2), 140-156. retrieved from http://journal.stainkudus.ac.id/ index.php/jmtk

Wang, L., Ertmer, P. A., \& Newby, T. J. (2004). Increasing preservice teachers' beliefs for technology integration. Journal of Research on Computing in Education, 36(3), 231-250 